AKUNTABILITAS

Vol. VII No. 2, Agustus 2014

P-ISSN: 1979-858X

Halaman $145-152$

\title{
REAKSI PASAR TERHADAP PENGUMUMAN REVERSE SPLIT PADA PERUSAHAAN GO PUBLIC DI INDONESIA
}

\author{
Ketut Sonya Adnyani \\ I Gusti Ayu Made Asri Dwija Putri \\ Universitas Udayana, Bali, Indonesia
}

\begin{abstract}
The purpose of this research was to determine how the market reacts because of the reverse split announcement. Market reaction seen from the difference in abnormal return before and after the company did a reverse split announcement. This research was conducted in 2001-2012. The samples used in this study were 20 companies. This is an 11-day observation period. The data used in this study is a secondary data and a purposive sampling method was used to determining samples. Technical analysis used for different test is wilcoxon signed rank test. The results of the study shows that the market reacted to the reverse split announcement, marked by the difference in abnormal return before and after reverse split.
\end{abstract}

Keywords: Reverse Split, Abnormal Return, The Market Reaction

ABSTRAK: Tujuan dari penelitian ini adalah untuk mengetahui bagaimana pasar bereaksi karena pengumuman reverse split. Reaksi pasar dilihat dari perbedaan abnormal return sebelum dan setelah perusahaan melakukan pengumuman reverse split. Penelitian ini dilakukan di 2001-2012. Sampel yang digunakan dalam penelitian ini adalah 20 perusahaan. Ini merupakan periode pengamatan 11 hari. Data yang digunakan dalam penelitian ini adalah data sekunder dan metode purposive sampling digunakan untuk menentukan sampel. Analisis teknis yang digunakan untuk tes yang berbeda wilcoxon signed rank test. Hasil penelitian menunjukkan bahwa pasar bereaksi terhadap pengumuman reverse split, ditandai dengan perbedaan abnormal return sebelum dan sesudah reverse split.

Kata kunci: Reverse Split, Abnormal Return, Reaksi Pasar

Draft pertama: 27 Maret 2014 ; Revisi 19 April 2014 ; Diterima: 24 Mei 2014

*Penulis dapat dikontak melalui: igamasri@yahoo.com 


\section{PENDAHULUAN}

Pasar modal memiliki peranan yang penting dalam meningkatkan pertumbuhan ekonomi. Perekonomian suatu negara sangat dipengaruhi oleh keberadaan pasar modal sehingga mampu memenuhi kebutuhan indsutri maupun enititas lainnya terhadap modal. Salah satu peran dari pasar modal adalah memberi kesempatan untuk berinvestasi dan memperoleh sejumlah hasil (return) yang diharapkan. Demi menunjang adanya investasi yang tepat, tentu diperlukan beberapa informasi yang dimiliki oleh investor sebagai pihak yang akan menanamkan modal. Pada umumnya, dalam proses pengambilan keputusan investasi, investor mempertimbangkan faktor informasi akuntansi. Informasi akuntansi diprediksi memiliki nilai relevansi, karena informasi akuntansi secara statistik berhubungan dengan nilai pasar (Puspitaningtyas, 2012).

Tidak semua informasi yang berada di pasar modal dapat dijadikan sebagai pertimbangan dalam pengambilan keputusan, informasi berupa corporate action banyak menarik perhatian investor. Reverse split merupakan salah satu dari corporate action yang dilakukan oleh perusahaan yang ada di Indonesia. Reverse split adalah peristiwa penggabungan saham dengan rasio tertentu sehingga akan meningkatkan nilai nominalnya. Di Indonesia, corporate action berupa reverse split pertama kali dilakukan pada tahun 2001 oleh PT. Bank Danamon, Tbk. Hal ini dilakukan dengan tujuan untuk menghindari kriteria delisting dan membentuk harga saham diatas Rp 50,00 per saham seperti dimuat di Bisnis Indonesia dalam Fransiska dan Purwaningsih (2011).

Pengumuman reverse split dikatakan mengandung informasi (information content), jika informasi tersebut menimbulkan reaksi pasar setelah pengumuman tersebut diterima oleh pasar. Reaksi pasar ini tercermin dari harga saham yang berubah-ubah dan diukur dengan adanya abnormal return yang diterima oleh pelaku pasar (Wafiyah, 2005). Jumlah perusahaan yang melakukan reverse split di Indonesia relatif sedikit apabila dibandingkan stock split, hal ini dikarenakan reverse split umumnya memberikan sinyal negatif kepada publik karena akan menggambarkan keadaan perusahaan yang kurang mempunyai prospek di masa depan.

Penelitian oleh Savitri dan Martani (2006) menemukan bahwa terdapat abnormal return yang negatif dan signifikan pada hari di sekitar peristiwa reverse split. Kim et al (2008) juga menyebutkan bahwa terdapat abnormal return yang negatif pada peristiwa reverse split. Namun, hasil berbeda dikemukakan oleh Masse et al (1997) dimana ditemukan bahwa terdapat abnormal return yang positif pada peristiwa reverse split yang terjadi di Kanada. Sedangkan penelitian oleh Jog dan Zhu (2004) mengungkapkan bahwa tidak adanya sinyal yang timbul dalam peristiwa reverse split.

Berdasarkan penjelasan diatas terlihat masih terdapat perbedaan terhadap hasil penelitian yang dilakukan dan terbatasnya penelitian di Indonesia mengenai reverse split sehingga terdapat masalah yang dapat dirumuskan, yaitu: Apakah terdapat perbedaan abnormal return sebelum dan sesudah pengumuman reverse split?

Penelitian ini diharapkan bermanfaat agar bisa memberikan informasi dan referensi kepada investor, perusahaan dan peneliti selanjutnya mengenai keputusan investasi yang bisa diambil yang berhubungan dengan reverse split.

\section{KERANGKA TEORI DAN PENGEMBANGAN HIPOTESIS}

Reaksi pasar yang timbul dari pengumuman reverse split akan dilihat dari adanya perbedaan terhadap abnormal return sebelum dan sesudah reverse split. Jing (2008) menyatakan terdapat empat alasan utama perusahaan melakukan reverse split, yaitu (1) reverse split akan mengurangi biaya transaksi, karena terjadi pengurangan jumlah saham yang beredar, (2) reverse split akan memperbaiki fleksibilitas harga saham baru ketika dibutuhkan, (3) reverse split akan meningkatkan investor institusional dan internasional dan (4) reverse split dapat membawa nilai saham yang sesungguhnya. Dengan adanya 
reverse split harga saham di pasar akan cenderung naik, sehingga saham tersebut akan dipandang sebagai saham yang tidak murahan.

\section{Teori Sinyal (Signalling Theory)}

Dalam teori sinyal digambarkan mengenai informasi yang dikeluarkan oleh perusahaan bisa sampai kepada publik yang selanjutnya akan dinilai apakah itu merupakan good news atau bad news. Dalam hal ini publik berlaku sebagai pihak yang miskin akan informasi, sedangkan perusahaan adalah pihak yang memiliki informasi lebih. Akibat adanya asimetri informasi inilah maka apabila perusahaan mengeluarkan informasi maka akan direspon oleh pasar sebagai sinyal yang mengakibatkan perubahan terhadap harga saham tersebut. Menurut Han (1995) perusahaan yang melakukan reverse split justru menunjukkan bahwa pihak manajemen kurang percaya diri terhadap perkembangan perusahaan di masa depan. Hal ini serupa dengan yang diungkapkan Fransiska dan Purwaningsih (2011), reverse split justru dianggap memberikan sinyal negatif tentang prospek masa depan perusahaan. Menurut Hartono (2010:517), jika suatu informasi yang relevan masuk ke pasar yang berhubungan dengan suatu aktiva, informasi ini akan digunakan untuk menganalisis dan menginterpretasikan nilai dari aktiva yang bersangkutan. Apabila hal itu terjadi maka kemungkinan terjadi pergeseran ke harga ekuilibrium yang baru.

\section{Penggabungan Saham (Reverse Split)}

Susiyanto (dalam Amir Hamzah, 2006) bahwa penggabungan saham (reverse split) merupakan aksi emiten yang berkebalikan dengan stock split, yaitu dengan cara menggabungkan nilai nominal saham menjadi nominal yang lebih besar sesuai dengan rasio reverse split yang telah ditentukan, dimana perubahan nilai nominal tersebut hanya mengakibatkan pengurangan jumlah lembar saham, tetapi tidak mengubah jumlah modal ditempatkan dan modal disetor (paid in capital). Dengan kata lain seperti halnya aksi stock split (pemecahan saham), aksi reverse split (penggabungan saham) juga tidak akan mengurangi atau menambah nilai investasi atau modal dari pemegang saham investor. Tujuan perusahaan melakukan reverse split itu bukan hanya untuk menyelamatkan perusahaannya dari delisting, namun persepsi pasar sudah terlanjur memberikan pandangan negatif kepada perusahaan yang melakukan reverse split sebagai perusahaan yang memiliki kinerja yang buruk. Hal ini memliliki efek negatif pada harga saham, terutama selama hari-hari menjelang reverse split (Sugito, 2009).

\section{Abnormal Return}

Menurut Hartono (2010:579), abnormal return merupakan kelebihan dari return yang sesungguhnya terjadi terhadap return normal yang merupakan return yang diharapkan oleh investor (expected return). Selisih return akan positif jika return yang didapatkan lebih besar dari return yang diharapkan atau return yang dihitung. Sedangkan return akan negatif jika return yang didapat lebih kecil dari return yang diharapkan atau return yang dihitung. Studi peristiwa menganalisis return tidak normal dari sekuritas yang mungkin terjadi disekitar pengumuman dari suatu peristiwa. Abnormal return terjadi karena dipicu oleh adanya kejadian atau peristiwa-peristiwa tertentu. Abnormal return adalah selisih antara return sesungguhnya yang terjadi dengan return ekspekstasian. Abnormal return dapat dihitung dengan menggunakan market model, mean adjusted model dan market adjusted model (Hartono, 2010:579)

Penelitian mengenai reverse split sudah pernah dilakukan, namun jumlahnya sangat terbatas dan memberikan hasil yang tidak konsisten seperti penelitian oleh Han (1995) yang memberikan simpulan bahwa terdapat abnormal return yang negatif pada peristiwa reverse split, sedangkan penelitian oleh Masse et al (1997) menjelaskan bahwa terdapat abnormal 
return yang positif sehingga dapat dikatakan bahwa reverse split merupakan good news bagi pasar. Kedua penelitian tersebut juga tidak konsisten dengan hasil penelitian oleh Chalida (2010) yang menyatakan bahwa tidak terdapat perbedaan abnormal return dan volume perdagangan pada peristiwa reverse split.

Penelitian oleh Memon (2003) menemukan bahwa terdapat perubahan pada return berupa penurunan abnormal return yang signifikan setelah reverse split dilakukan. Hal ini bisa dikaitkan dengan fakta bahwa perusahaan yang melakukan reverse split merupakan saham yang underperforms. Penelitian oleh Maberly dan Pierce (2004) menemukan bahwa terjadi penurunan pada return pada hari sebelum dan sesudah reverse split. Hal serupa juga dikemukakan oleh Savitri dan Martani (2006) yang menemukan bahwa terdapat abnormal return yang negatif dan signifikan pada hari di sekitar peristiwa reverse split. Neuhauser dan Thompson (2013) juga konsisten menemukan bahwa terdapat return yang negatif setelah peristiwa reverse split. Maka, dirumuskan hipotesis sebagai berikut:

$\mathbf{H}_{\mathbf{1}}$ : Terdapat perbedaan abnormal return sebelum dan sesudah reverse split pada perusahaan-perusahaan go public di Indonesia.

\section{METODE PENELITIAN}

Penelitian ini menggunakan data sekunder mengenai perusahaan-perusahaan go public di Indonesia yang melakukan corporate action berupa reverse split dengan mengakses website www.idx.co.id dan www.ksei.co.id dan untuk mengakses harga saham harian melalui www.finance.yahoo.com dan www.duniainvestasi.com. Objek penelitian ini adalah reaksi pasar berupa abnormal return pada perusahaan-perusahaan go public di Indonesia yang melakukan corporate action berupa reverse split.

Dalam penelitian ini yang dijadikan populasi adalah seluruh perusahaan go public di Indonesia yang melakukan corporate action berupa reverse split. Sampel adalah bagian dari jumlah karakteristik yang dimiliki oleh populasi tersebut. Sampel akan diambil dari populasi tersebut menggunakan metode purposive sampling. Adapun kriteria yang digunakan adalah:

1) Perusahaan go public di Indonesia yang melakukan corporate action berupa reverse split.

2) Perusahaan tidak melakukan corporate action lain seperti right issue, pengumuman laba, pembagian dividen selama periode pengamatan.

3) Tersedianya data perusahaan yang lengkap.

\section{Definisi Operasional Variabel}

\section{Reverse Split}

Periode pengamatan yang digunakan dalam penelitian ini adalah jendela peristiwa selama 11 hari yaitu 5 hari sebelum pengumuman $(\mathrm{H}-5), 1$ hari saat pengumuman (event date, $\mathrm{H}=\mathrm{O}$ ) dan 5 hari sesudah tanggal pengumuman $(\mathrm{H}+5)$. Alasan penggunaan jendela peristiwa selama 11 hari adalah karena peristiwa reverse split merupakan informasi yang mudah dicerna sehingga hanya memerlukan periode jendela yang singkat. Periode ini juga merupakan periode yang umum digunakan berdasarkan penelitian sebelumnya, seperti penelitian oleh Hendrawijaya Dj (2009), Chalida (2010) dan Fransiska dan Purwaningsih (2011).

\section{Abnormal return}

Abnormal return merupakan variabel terikat yang diukur dengan menselisihkan return sesungguhnya yang terjadi dengan return ekspektasian (Hartono, 2010:580). Penelitian ini menggunakan Market Adjusted Model. Pemilihan metode ini didasarkan oleh penelitian sebelumnya oleh Januar (2011) dan Pramana (2012). Adapun langkah-langkah untuk menghitung abnormal return adalah sebagai berikut :

1. Return Individual (Rit) 


$$
\text { Rit }=\frac{P_{t}-P_{t-1}}{P_{t-1}}
$$

Keterangan:

Rit : return individual saham $\mathrm{i}$ pada saat $\mathrm{t}$

Pt : harga penutupan saham $i$ pada saat $t$

Pt-1: harga penutupan saham i pada saat t-1

2. Return Pasar (Rmt)

$$
R m t=\frac{I H S G_{t}-I H S G_{t-1}}{I H S G_{t-1}}
$$

Keterangan:

Rmt: tingkat return pasar pada saat $\mathrm{t}$

IHSGt: Indeks Harga Saham Gabungan pada saat $\mathrm{t}$

IHSGt-1: Indeks Harga Saham Gabungan pada saat t-1

3. Abnormal Return

$$
\mathrm{AR}_{\mathrm{t}}=\mathrm{R}_{\mathrm{it}}-\mathrm{Rm}_{\mathrm{t}}
$$

Keterangan:

ARt: abnormal return saham i saat $\mathrm{t}$

Rit: return individual saham i saat $\mathrm{t}$

Rmt: tingkat return saham saat $\mathrm{t}$

\section{HASIL DAN PEMBAHASAN}

Menurut kriteria sampel yang ditetapkan, maka dipilih 20 perusahaan yang akan dijadikan sampel. yaitu perusahaan go public di Indonesia yang melakukan reverse split dan tidak melakukan corporate action lainnya pada periode pengamatan. Adapun periode pengamatan dalam penelitian ini adalah 11 hari. Dalam waktu 11 hari akan dihitung abnormal return yang dihasilkan, untuk selanjutnya dilakukan perhitungan rata-rata terhadap abnormal return sebelum dan sesudah peristiwa reverse split. Pertama dilakukan pengujian data secara statistik deskriptif, dimana hasilnya adalah sebagai berikut:

Tabel 1. Hasil Uji Deskriptif Abnormal Return Sebelum dan Sesudah Pengumuman Reverse Split

Descriptive Statistics

\begin{tabular}{|l|r|r|r|r|r|}
\hline & \multicolumn{1}{|c|}{$\mathrm{N}$} & \multicolumn{1}{|c|}{ Minimum } & Maximum & \multicolumn{1}{c|}{ Mean } & Std. Deviation \\
\hline Pre_reverse_split & 20 & -.1419 & 3.6101 & .182495 & .8076634 \\
Post_reverse_split & 20 & -.1761 & .1296 & -.026095 & .0671653 \\
Valid N (listwise) & 20 & & & & \\
\hline
\end{tabular}

Sumber: Output SPSS 13.0

Tabel 1 menunjukkan bahwa jumlah observasi untuk reverse split adalah sebanyak 20 perusahaan. Nilai minimum abnormal return sebelum reverse split adalah -0.1419 yang dimiliki oleh PT. Bakrie \& Brothers Tbk yang melakukan reverse split pada tahun 2005. Sedangkan nilai maksimum abnormal return adalah 3,6101 yaitu milik PT. Smartfren Telecom Tbk yang melakukan reverse split pada tahun 2012, tingginya abnormal return diakibatkan adanya perbedaan harga yang tinggi pada hari pengamatan. Rata-rata abnormal return sebelum perusahaan melakukan reverse split adalah 0.182495 dengan standar deviasi o.8076634. Selanjutnya, dilakukan pengujian abnormal return sesudah peristiwa reverse split, dimana dihasilkan nilai minimum abnormal returnnya adalah -0.1761 yang dimiliki oleh PT. Smartfren Telecom Tbk. Nilai maksimum abnormal return adalah o,1296 yang 
dimiliki oleh PT. Nusantara Infrastructure Tbk. Nilai rata-rata abnormal return sesudah reverse split adalah -0.026095 dengan standar deviasi 0.0671653. Dari uji statistik diatas dapat dilihat terjadi penurunan terhadap rata-rata abnormal return sesudah terjadinya reverse split maka terjadi penurunan abnormal return sebesar 0,20859.

Selanjutnya akan dilakukan pengujian hipotesis, namun akan dilakukan pengujian normalitas terhadap data itu terlebih dahulu, untuk mendeteksi normalitas data dari variabel yang digunakan. Uji normalitas ini nantinya juga akan menentukan uji hipotesis yang sesuai digunakan. Hasil uji normalitasnya adalah sebagai berikut:

Tabel 2. Hasil Uji Normalitas Abnormal Return Sebelum dan Sesudah Pengumuman Reverse Split

One-Sample Kolmogorov-Smirnov Test

\begin{tabular}{|ll|r|r|}
\hline & & $\begin{array}{r}\text { Pre_reverse_ } \\
\text { split }\end{array}$ & \multicolumn{1}{c|}{$\begin{array}{c}\text { Post_split } \\
\text { reverse_split }\end{array}$} \\
\hline $\mathrm{N}$ & & 20 & 20 \\
Normal Parameters ${ }^{\mathrm{a}, \mathrm{b}}$ & Mean & .182495 & -.026095 \\
& Std. Deviation & .8076634 & .0671653 \\
Most Extreme & Absolute & .516 & .169 \\
Differences & Positive & .516 & .169 \\
& Negative & -.357 & -.104 \\
Kolmogorov-Smirnov Z & & 2.306 & .754 \\
Asymp. Sig. (2-tailed) & & .000 & .621 \\
\hline
\end{tabular}

a. Test distribution is Normal.

b. Calculated from data.

Sumber: Output SPSS 13.0

Dari hasil yang ditampilkan di tabel 2 terlihat bahwa abnormal return sebelum peristiwa reverse split bernilai o.ooo, hal ini berarti bahwa abnormal return sebelum reverse split memiliki distribusi yang tidak normal karena lebih kecil dari nilai probabilitasnya yaitu 5 persen. Selanjutnya untuk data abnormal return sesudah peristiwa reverse split nilainya adalah o,621 yang memiliki nilai lebih besar dari 5 persen maka data berdistribusi normal. Namun, karena salah satu data tidak berdistribusi normal maka dalam penelitian ini akan digunakan uji non parametrik yaitu uji beda Wilcoxon Signed Rank Test.

Setelah melakukan uji normalitas, maka akan dilakukan pengujian hipotesis penelitian dengan menggunakan uji beda Wilcoxon Signed Rank Test. Adapun hasil dari uji beda tersebut adalah:

\section{Tabel 3. Hasil Uji Wilcoxon Signed Rank Test Terhadap Abnormal Return Sebelum dan Sesudah Reverse Split}

\begin{tabular}{|ll|r|r|r|}
\hline \multicolumn{1}{|c|}{ Ranks } \\
\hline Post_reverse_split & Negative Ranks & N & Mean Rank & Sum of Ranks \\
\hline - Pre_reverse_split & Positive Ranks & $5^{\mathrm{a}}$ & 10.73 & 161.00 \\
& Ties & $5^{\mathrm{b}}$ & 9.80 & 49.00 \\
& Total & $0^{\mathrm{c}}$ & & \\
& 20 & & \\
\hline
\end{tabular}
a. Post_reverse_split < Pre_reverse_split
b. Post_reverse_split > Pre_reverse_split
C. Post_reverse_split $=$ Pre_reverse_split 


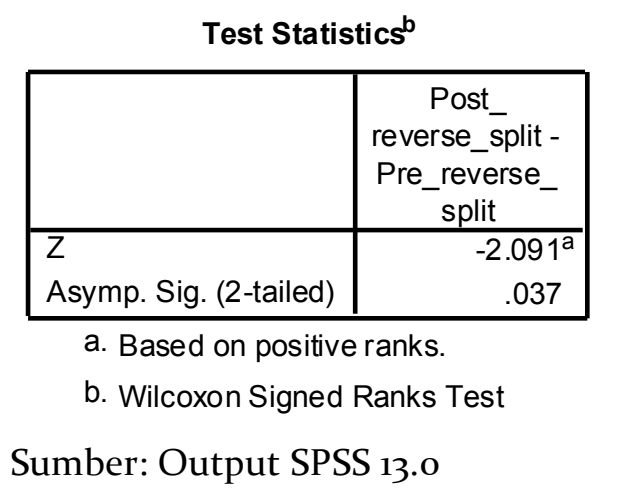

Berdasarkan tabel 3 dapat dilihat bahwa terdapat 15 dari 20 sampel perusahaan yang memiliki nilai abnormal return yang lebih rendah sesudah terjadinya reverse split. Untuk peningkatan abnormal return sesudah peristiwa reverse split hanya terjadi pada 5 perusahaan. Dapat disimpulkan bahwa lebih banyak terjadi penurunan abnormal return pada peristiwa reverse split. Pada tes statistik ini terdapat nilai signifikansi o.o37 yang berarti lebih kecil dari 5 persen, maka $\mathrm{H}_{1}$ diterima. Hal ini menjelaskan bahwa memang terjadi perbedaan abnormal return sebelum dan sesudah peristiwa reverse split pada perusahaan go public di Indonesia.

Berdasarkan teori sinyal maka dapat dijelaskan bahwa reverse split menghasilkan sinyal yang mengakibatkan pasar akan bereaksi. Investor yang memiliki informasi tersebut akan segera menjual sahamnya yang akan mengakibatkan turunnya harga saham yang bersangkutan dan berpengaruh pada abnormal returnnya. Reverse split dianggap sebagai berita buruk karena perusahaan yang melakukan reverse split justru menunjukkan bahwa pihak manajemen kurang percaya diri terhadap perkembangan perusahaan di masa depan Han (1995). Hal ini serupa dengan yang diungkapkan Savitri dan Martani (2006), Fransiska dan Purwaningsih (2011) serta Neuhauser dan Thompson (2013) yang menemukan bahwa terdapat return yang negatif setelah peristiwa reverse split.

\section{SIMPULAN}

Berdasarkan atas analisis dan pembahasan hasil penelitian yang telah diuraikan pada bab sebelumnya, maka dapat disimpulkan yaitu terdapat perbedaan abnormal return yang signifikan sebelum dan sesudah peristiwa reverse split pada perusahaan go public di Indonesia. Secara teoritis hal ini sesuai dengan teori sinyal, bahwa reverse split dapat memberikan sinyal kepada publik. Adanya abnormal return yang negatif mengindikasikan bahwa peristiwa reverse split merupakan bad news bagi investor karena mengakibatkan adanya abnormal return yang negatif.

\section{DAFTAR PUSTAKA}

Chalida, Wediastri. 2010. Pengujian Efisiensi Pasar Berbentuk Setengah Kuat Secara Keputusan dengan Analisis Stock Split dan Reverse Split. Jurusan Manajemen Fakultas Ekonomi dan Sosial, Universitas Islam Syarif Hidayatullah Jakarta.

Fransiska, Lusiana dan Anna Purwaningsih. 2011. Perbedaan Likuiditas Saham Sebelum dan Sesudah Reverse Stock Split (Studi empiris pada Bursa Efek Indonesia). Fakultas Ekonomi Universitas Atma Jaya Yogyakarta.

Hamzah, Amir. 2006. Analisis Kinerja Saham Perbankan Sebelum E Sesudah Reverse Stock Split Di Pt. Bursa Efek Jakarta. Jurnal Manajemen \& Bisnis Sriwijaya Vol. 4, No 8 Desember 2006.

Han, Ki C. 1995. The Effects of Reverse Splits on The Liquidity of The Stock. Journal of Financial and Quantitative Analysis, (March). Pg 159. 
Hartono, Jogiyanto. 2010. Teori Portofolio dan Analisis Investasi.Yogyakarta: BPFE

Hendrawijaya Dj, Michael. 2009. Analisis Perbandingan Harga Saham, Volume Perdagangan Saham, Dan Abnormal Return Saham Sebelum Dan Sesudah Pemecahan Saham (Studi pada perusahaan go public yang melakukan pemecahan saham antara tahun 2005 - 2008 di BEI). Tesis Program Studi Magister Manajemen Universitas Diponegoro.

Januar, Dedy. 2011. Analisis Dampak Pengumuman Stock Split dan Reverse Stock Split Terhadap Abnormal Return dan Perubahan Beta Saham.Skripsi Jurusan Manajemen Fakultas Ekonomi dan Bisnis Universitas Islam Negeri Jakarta Syarif Hidayatullah.

Jing, Lihua. 2008. Why Firms Consolidate their Stocks?. SSRN Accounting Journal.

Jog, Vijay and PengCheng Zhu. 2004. Thirty years of Stock Splits, Reverse Stock Splits, and Stock Dividends in Canada. Sprott School of Business, Carleton University.

Kim, Seoyoung, April Klein and James Rosenfeld. 2008. Return Performance Surrounding Reverse Stock Split:Can Investors Profit ?. Financial Management Summer 2008 Pages 173-192.

Maberly, Edwin D. and Raylene M. Pierce. 2004. Reconciling Theory with Post-reverse Split Return Patterns: Empirical Findings Based on Recent Events.

Martell, Terrence F and Gwendolyn P. Webb. 2005. The Performance of Stocks That Are Reverse Split. Department of Economics and Finance, Baruch College/The City University of New York.

Masse, Isidore, Hanrahan, J R, Kushner, Joseph. 1997. The Effect of Canadian Stock Splits, Stock Dividens, and Reverse Splits on The Value of Firm. Quarterly Journal of Business and Economics; Autumn 1997; 36, 4; ProQuest pg. 51

Memon, Mohsin. 2003. Impact and Value of Reverse Stock Split. Thesis Bachelor of Science Undergraduate College Leonard N. Stren School of Business New York University.

Neuhauser, K. L. \& Thompson, T. H. 2013. An Examination of the Survivability of Reverse Stock Splits:If they lose value,then then why do Companies continue to perform Reverse Splits? Financial Management Association, Chicago, Illinois.

Pramana, Adi. 2012. Analisis Perbandingan Trading Volume Activity Dan Abnormal Return Saham Sebelum Dan Sesudah Pemecahan Saham. Skripsi Jurusan Manajemen Fakultas Ekonomika Dan Bisnis Universitas Diponegoro Semarang.

Puspitaningtyas, Zarah. 2012. Relevansi Nilai Informasi Akuntansi dan Manfaatnya Bagi Investor. Jurnal Ekonomi dan Keuangan Universitas Jember.

Savitri, Melinda and Dwi Martani. 2006. The Analisys Impact Of Stock Split And Reverse Stock Split On Stock Return And Volume The Case Of Jakarta Stock Exchange. University of Indonesia.

Sugito, Wisudowati Ayu. 2009. Analisis Motivasi Dibalik Stock Split dan Reverse Stock Split:Pembuktian Pada Likuiditas dan Return Saham. Skripsi Jurusan Manajemen Fakultas Ekonomi dan Sosial, Universitas Islam Syarif Hidayatullah Jakarta.

Wafiyah. 2005. Reaksi Pasar Pada Pengumuman Stock Split Dan Reverse Split (Study Pada Perusahaan Yang Terdaftar Di Bej). Tesis Program Studi Magister Manajemen Program Pascasarjana Universitas Diponegoro Semarang.

www.ksei.co.id "List of Stock Split and Reverse Stock" diakses tanggal 14 Mei 2014.

www.idx.co.id "IDX Yearly Statistics". Diakses tanggal 15 Mei 2014.

www.duniainvestasi.com "Historical Prices" diakses tanggal 20 Mei 2014. 